\title{
Additional secure circular suture during sphincteroplasty - preliminary results on the efficacy of fecal incontinence surgery in urogynecological patients
}

\author{
Aneta Adamiak-Godlewska ${ }^{1}$, Katarzyna Skorupska ${ }^{1}$, Katarzyna Romanek-Piva ${ }^{1}$, \\ Jacek Piłat ${ }^{2}$, Tomasz Rechberger $^{1}$ \\ 'Il Chair and Department of Gynaecology, Medical University of Lublin, Poland \\ 2I Chair and Department of General and Transplant Surgery and Nutritional Treatment, Medical University of Lublin, Poland
}

\begin{abstract}
Objectives: The paper is a ten case series study presenting women with complex pelvic floor disorders involving fecal incontinence $(\mathrm{FI})$ with stress urinary incontinence or pelvic organ prolapse.

Our study aimed at ascertaining whether Fl-induced sphincteroplasty with an additional secure circular suture around the external anal sphincter muscle (EAS) may improve long term success rates.

Materials and methods: Twelve patients had scheduled urogynecological surgery and overlapping sphincteroplasty with the placement of an additional circular suture around the EAS. Of these, the status of ten women was established by way of the Cleveland Clinic Fecal Incontinence Score/Wexner Score before and about 70 months after surgery.

Results: Statistical analysis of fecal incontinence score showed that patients were not completely cured from Fl, but were significantly better $(p=0.011)$.

Conclusions: A circular secure suture around the external anal sphincter in FI patients may help to improve anal sphincter function.
\end{abstract}

Key words: fecal incontinence; pelvic organ prolapse; urinary incontinence; sphincteroplasty

Ginekologia Polska 2019; 90, 2: 82-85

\section{INTRODUCTION}

Women fecal incontinence (FI) due to obstetric injuries and "end-to-end" or an "overlap" sphincteroplasty the most commonly used surgical techniques to fix the problem. Post-operative complications are generally low, but success declines with post-procedure time. Indeed, only $28 \%$ were continent at 40 months in one study [1] and predicted median time to $\mathrm{Fl}$ relapse postsphincteroplasty is five years [2]. If an end-to-end repair is performed after a significant delay from primary injury, outcomes are poorer than an overlapping repair. Outpatient clinic data reveal FI prevalence of $5.6 \%$ in the general population and $15.9 \%$ in urogynecological patients [3]. Herein, some patients also needed surgery because of vaginal or uterine prolapse or stress urinary incontinence (SUI).

\section{Objectives}

Our study aimed at ascertaining whether Fl-induced sphincteroplasty with an additional secure circular suture around the external anal sphincter muscle (EAS) may improve long term success rates.

\section{MATERIALS AND METHODS}

The study group consisted of 12 urogynecological patients afflicted with FI because of EAS injury - (Tab. 1). All patients provided informed consent to participate in the study, and the study was approved by the Medical University Ethical Board.

Fl severity was evaluated via Cleveland Clinic Fecal Incontinence Score (CCFIS)/Wexner Score pre-/post-surgery. The summary score is derived from 5 parameters, the fre- 
Table 1. Characteristics of the patients. Surgery procedures: $1-$ T-sling; $2-$ TVM anterior; $3-$ TVM posterior; $4-$ distal levatorplasty; 5 - sphincteroplasty with circular suture; 6 - total vaginal hysterectomy

\begin{tabular}{|c|c|c|c|c|c|c|c|c|}
\hline No & Initials & $\begin{array}{l}\text { Age } \\
\text { (years) }\end{array}$ & $\begin{array}{l}\text { BMI } \\
\left(\mathrm{kg} / \mathrm{m}^{2}\right)\end{array}$ & $\begin{array}{l}\text { No of } \\
\text { vaginal deliveries }\end{array}$ & $\begin{array}{l}\text { No of } \\
\text { cc }\end{array}$ & Clinical diagnosis & Surgery & $\begin{array}{l}\text { Observation time } \\
\text { (months) }\end{array}$ \\
\hline 1. & SL & 54 & 28.3 & 3 & 0 & POPQ IIlallp, FI & $1,4,5$ & 79 \\
\hline 2. & WA & 31 & 21.1 & 1 & 0 & $\begin{array}{l}\text { 3-rd degree obstetric injury } 6 \mathrm{mths} \\
\text { before, } \mathrm{POPQ} \text { IIp, FI }\end{array}$ & 4,5 & 75 \\
\hline 3. & $\mathrm{BH}$ & 49 & 34.0 & 3 & 0 & SUI, FI & $1,4,5$ & 73 \\
\hline 4. & BP & 38 & 25.8 & 1 & 1 & SUI, FI & $1,4,5$ & 71 \\
\hline 5. & TL & 65 & 32.0 & 3 & 0 & SUI, POPQ IIp, FI & $1,4,5$ & 71 \\
\hline 6. & ZU & 67 & 38.0 & 1 (forceps) & 2 & SUI, FI & $1,4,5$ & 68 \\
\hline 7. & MS & 66 & 25.0 & 2 & 0 & POPQ IIIallp IIlc, SUI, FI & $1,4,5,6$ & 68 \\
\hline 8. & AN & 50 & 23.8 & 2 & 0 & SUI, FI & $1,4,5$ & 63 \\
\hline 9. & RS & 26 & 23.3 & 1 & 0 & $\begin{array}{l}\text { 3-rd degree obstetric injury } 7 \text { mths } \\
\text { before, POPQ IIp, FI }\end{array}$ & 4,5 & 51 \\
\hline 10. & ZJ & 76 & 27.0 & 2 (forceps) & 0 & SUI, FI & $1,4,5$ & 40 \\
\hline 11. & BW & 56 & 26.7 & 3 & 0 & POPQ IVc, SUI, FI & $1,2,3,4,5$ & 28 \\
\hline 12. & KS & 74 & 24.2 & 3 & 0 & POPQ IVc, SUI, FI & $1,2,3,4,5$ & 33 \\
\hline
\end{tabular}

quency of which is ranked on a scale from 0 (= absent) to 4 (daily): incontinence to solid stool, to liquid stool, or to gas, need to wear a pad, and lifestyle changes. A score of 0 means perfect control, a score of 20 complete incontinence [4]. EAS defect was confirmed preoperatively by endoanal ultrasound. $3 \mathrm{D}$ volumes were obtained by using a $360^{\circ}$ mechanical rotational probe with the automatic $3 \mathrm{D}$ acquisition (type 2052, Ultraview-800; BK-Medical), at a frequency of $13 \mathrm{MHz}$. All women had scheduled urogynecological surgery and overlapping sphincteroplasty $[5,6]$ with the placement of an additional circular suture around the EAS to secure proper tension-free healing of the muscle - Figures 1, 2, 3. Briefly, a perineal incision was used with inverted-U incision at the outer edge of the external sphincter of up to $180^{\circ}$ to allow healthy muscle exposure (Fig. 1). The sphincter muscle was then mobilized from the fatty tissue, and the severed ends were reapproximated en bloc with both the internal and the external sphincter by way of placement of, typically, 4-6 slow reabsorbing sutures. In such surgery, the incision should not be extended passed $180^{\circ}$ to avoid pudendal nerve injury. In the more common delayed repair, scar tissue which bridges the sphincter's distracted ends is maintained in situ while the sphincter muscle's severed ends are overlapped and held with long-term absorbable suture in a horizontal mattress fashion (Fig. 2). This repair lengthens the perineal body and the perineal incision comes together in a Y-shaped formation so that the incision mid-portion is left open for drainage. Next, the skin beneath the anus is incised minimally and a circular secure suture (similar to Shirodkar cervical cerclage - Ethibond-Excel 5, needle 55) is placed around the EAS (Fig. 3). A distal anterior levatorplasty is also performed to augment its function.

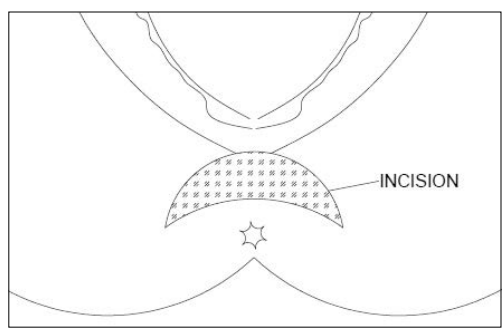

Figure 1. Sphincteroplasty - step 1. A perineal incision was used with inverted-U incision at the outer edge of the external sphincter of up to $180^{\circ}$ to allow healthy muscle exposure

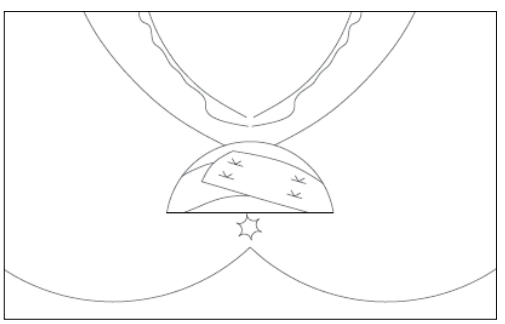

Figure 2. Sphincteroplasty - step 2. Typically, 4-6 slow reabsorbing sutures were placed

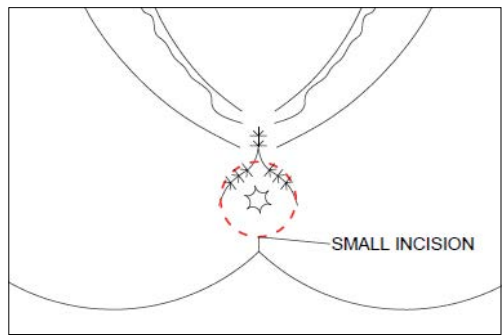

Figure 3. Sphincteroplasty and EAS circular secure suture - step 3. The skin beneath the anus is incised minimally and a circular secure is placed around the EAS 


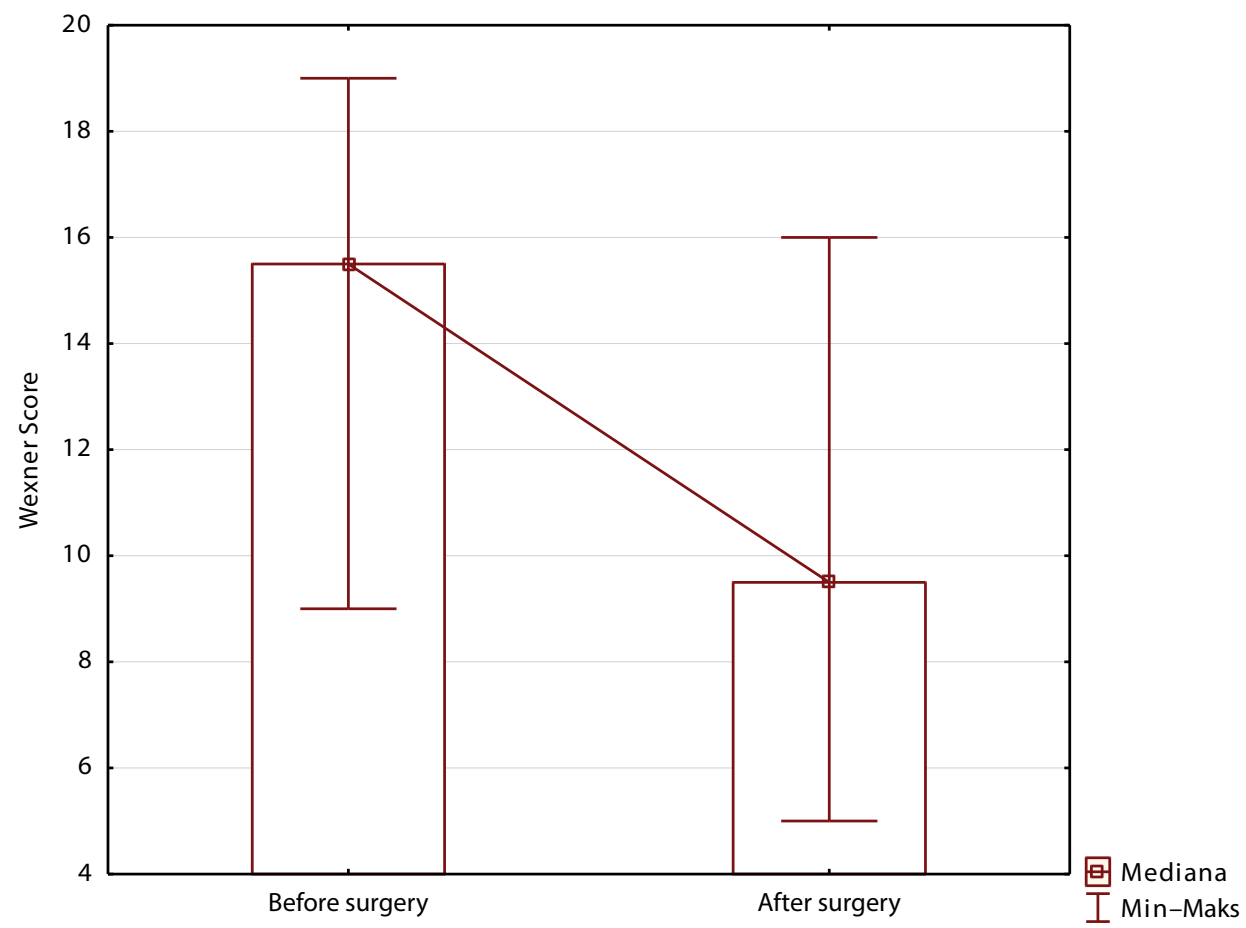

Figure 4. Wexner Score pre-/post-surgery

Post-operation, all patients were on a 5-day liquid diet with stool softeners throughout the postoperative period.

\section{RESULTS}

Final analysis of 10 women was performed ( 1 died in car accident, 1 lost in follow-up). Characteristics of these patients are shown in Table 2. Wexner Score pre-/postsurgery was compared using Statistica v. 12.0 software (StatSoft, Poland) (significance: $p<0.05$ ). Wilcoxon signed-rank test was also applied. The patients were not completely cured from FI but were significantly better $(p=0.011)$ (Fig.4). Circular secure suture around EAS on endoanal ultrasound scan presents (Fig.5).

\section{DISCUSSION}

Fecal incontinence, although less common than POP and SUI, is a very distressing condition also associated with substantial adverse affects the quality of life. The concomitant FI occurrence has been demonstrated in $21 \%$ of all patients with Ul and/or pelvic organ prolapse [7]. Overall, Jelovsek et al. [8] report that the odds of finding both $\mathrm{FI}$ and $\mathrm{UI}$ in their cohort of 302 urogynecology patients was 6.3 . In a cross-sectional survey of 174 patients with pelvic floor disorders, Bezerra et al. [9] found that patients affected by both FI and UI had significantly worse QoL scores than those with either condition alone. Combined $\mathrm{Fl}$ and $\mathrm{Ul}$ is also known to negatively impact patient QoL. The relationship between these three pelvic floor disorders is poorly understood and little investigated. The

\begin{tabular}{|l|l|}
\hline \multicolumn{2}{|l|}{ Table 2. Patient demographics - statistics } \\
\hline Patients $(\mathbf{n}=10)$ & Me (min-max) \\
\hline Age (years) & $59.5(31-76)$ \\
\hline BMl $(\mathrm{kg} / \mathrm{m} 2)$ & $26.4(21.1-38)$ \\
\hline Vaginal deliveries & $2(1-3)$ \\
\hline Caesarean section & $0(0-2)$ \\
\hline Observation time (months) & $69.5(33-79)$ \\
\hline
\end{tabular}

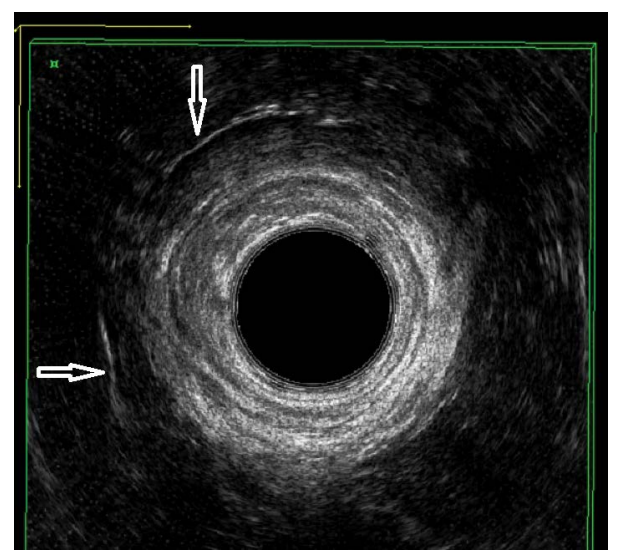

Figure 5. Endoanal ultrasound post-surgery. Arrows indicate the circular suture

pivotal clinical questions whether these symptoms shared the common pathological process, risk factors, or often co-exist simply by chance is still unanswered. Therefore the complex 
management of patients with such multiple pelvic floor disorders is always challenging and should be performed only in high-volume urogynecological departments.

According to our best knowledge, there are no clinical guidelines on complex surgery in patients affected by $\mathrm{FI}$ coexisting with UI and/or pelvic organ prolapse. Therefore we consider our study as preliminary. We decided to check the efficacy of modified by additional circular suture sphincteroplasty hoping that such suture allows proper tension-free healing of disrupted anal sphincter and will secure durability of repair as well. Numerous long-term studies have shown that the clinical efficacy of classical sphincteroplasty markedly decreases over time from $60 \%$ to even $0 \%$ [10-18]. We introduced an original additional new element to the classical overlapping sphincteroplasty namely circular secure suture around the EAS. By adding this suture we hope to increase the passive tone of the sphincter and actively secure proper tension-free healing of the repaired sphincter muscles.

In a recent Cochrane Review, Omar and Alexander [19] identified 6 trials for medications that enhance the anal sphincter tone (phenylephrine gel or sodium valproate) in patients with structurally intact anal sphincter. More people in these trials achieved full continence or improved incontinence symptoms, hence, EAS tone may help in fecal continence. The problem that arises is the adverse effects of these drugs when administered. These include localized dermatitis, burning sensation or headaches.

Many studies on sphincteroplasty have concluded that advanced age at the time of the surgery was a risk factor for long-term failure $[10,11,15]$, but a recent systematic review did not find any consistent factors, including age, that were predictive for failure [17]. In addition, a recent large retrospective review of 321 women did not show any significant difference in long-term severity of Fl, quality of life, or postoperative satisfaction between younger versus older women [20].

The problem of fecal incontinence coexisting with other pelvic floor dysfunction shows the need for physicians to cross disciplines or to create centres where urologists, gynecologists and colo-rectal surgeons can interact to manage complex patients [21].

\section{CONCLUSIONS}

Circular secure suture around EAS in Fl patients may help to improve anal sphincters function after classical overlapping sphincteroplasty however further studies are needed.

\section{REFERENCES}

1. Wald A. Clinical practice. Fecal incontinence in adults. $\mathrm{N}$ Engl J Med. 2007; 356(16): 1648-1655, doi: 10.1056/NEJMcp067041, indexed in Pubmed: 17442907.
2. McManus BP, Allison S, Hernánchez-Sánchez J. Anterior sphincteroplasty for fecal incontinence: predicting incontinence relapse. Int J Colorectal Dis. 2015 ; 30(4): 513-520, doi: 10.1007/s00384-015-2162-5, indexed in Pubmed: 25694138

3. Faltin DL, Sangalli MR, Curtin F, et al. Prevalence of anal incontinence and other anorectal symptoms in women. Int Urogynecol J Pelvic Floor Dysfunct. 2001; 12(2): 117-120; discussion 121, indexed in Pubmed: 11374509.

4. Jorge $M$, Wexner S. Etiology and management of fecal incontinence. Diseases of the Colon \& Rectum. 1993; 36(1): 77-97, doi: 10.1007/bf02050307.

5. Karram MM. Chirurgiczne leczenie nietrzymania stolca. In.: Baggish MS, (eds). Atlas chirurgii ginekologicznej i anatomii miednicy. Wyd polskie. ; 2009: 971-980.

6. Garlandand B, Hull T. Overlapping repair. In: Wexner SD, Fleshman JD (eds). Master Techniques in Surgery. Colon and Rectal Surgery: Anorectal Operations. Wolters Kluwer, Philadelphia. : 2012.

7. Jackson SL, Weber AM, Hull TL, et al. Fecal incontinence in women with urinary incontinence and pelvic organ prolapse. Obstet Gynecol. 1997; 89(3): 423-427, doi: 10.1016/S0029-7844(96)00499-1, indexed in Pubmed: 9052598.

8. Jelovsek JE, Barber MD, Paraiso MF, et al. Functional bowel and anorectal disorders in patients with pelvic organ prolapse and incontinence. Am J Obstet Gynecol. 2005; 193(6): 2105-2111, doi: 10.1016/j. ajog.2005.07.016, indexed in Pubmed: 16325624

9. Bezerra LR, Vasconcelos Neto JA, Vasconcelos CT, et al. Prevalence of unreported bowel symptoms in women with pelvic floor dysfunction and the impact on their quality of life. Int Urogynecol J. 2014; 25(7): 927-933, doi: 10.1007/s00192-013-2317-2, indexed in Pubmed: 24562788.

10. Oom DMJ, Gosselink MP, Schouten WR. Anterior sphincteroplasty for fecal incontinence: a single center experience in the era of sacral neuromodulation. Dis Colon Rectum. 2009; 52(10): 1681-1687, doi: 10.1007/DCR.0b013e3181b13862, indexed in Pubmed: 19966598.

11. Bravo Gutierrez A, Madoff RD, Lowry AC, et al. Long-term results of anterior sphincteroplasty. Dis Colon Rectum. 2004; 47(5): 727-31; discussion 731, doi: 10.1007/s10350-003-0114-6, indexed in Pubmed: 15037931.

12. Lehto K, Hyöty $M$, Collin $P$, et al. Seven-year follow-up after anterior sphincter reconstruction for faecal incontinence. Int J Colorectal Dis. 2013; 28(5): 653-658, doi: 10.1007/s00384-013-1663-3, indexed in Pubmed: 23440365.

13. Halverson AL, Hull TL. Long-term outcome of overlapping anal sphincter repair. Dis Colon Rectum. 2002; 45(3): 345-348, indexed in Pubmed: 12068192.

14. Maslekar S, Gardiner AB, Duthie GS. Anterior anal sphincter repair for fecal incontinence: Good longterm results are possible. J Am Coll Surg. 2007; 204(1): 40-46, doi: 10.1016/j.jamcollsurg.2006.10.008, indexed in Pubmed: 17189111.

15. Zutshi M, Tracey TH, Bast J, et al. Ten-year outcome after anal sphincter repair for fecal incontinence. Dis Colon Rectum. 2009; 52(6): 1089-1094, doi: 10.1007/DCR.0b013e3181a0a79c, indexed in Pubmed: 19581851.

16. Karoui S, Leroi AM, Koning $E$, et al. Results of sphincteroplasty in 86 patients with anal incontinence. Dis Colon Rectum. 2000;43(6): 813-820, indexed in Pubmed: 10859083.

17. Glasgow SC, Lowry AC. Long-term outcomes of anal sphincter repair for fecal incontinence: a systematic review. Dis Colon Rectum. 2012; 55(4): 482-490, doi: 10.1097/DCR.0b013e3182468c22, indexed in Pubmed: 22426274

18. Barisic Gl, Krivokapic ZV, Markovic VA, et al. Outcome of overlapping anal sphincter repair after 3 months and after a mean of 80 months. Int J Colorectal Dis. 2006; 21(1): 52-56, doi: 10.1007/s00384-004-0737-7, indexed in Pubmed: 15830204.

19. Omar MI, Alexander CE. Drug treatment for faecal incontinence in adults. Cochrane Database Syst Rev. 2013(6): CD002116, doi: 10.1002/14651858.CD002116.pub2, indexed in Pubmed: 23757096.

20. El-Gazzaz G, Zutshi M, Hannaway $C$, et al. Overlapping sphincter repair: does age matter? Dis Colon Rectum. 2012; 55(3): 256-261, doi: 10.1097/DCR.0b013e31823deb85, indexed in Pubmed: 22469791.

21. Mannella P, Giannini A, Russo E, et al. Personalizing pelvic floor reconstructive surgery in aging women. Maturitas. 2015; 82(1): 109-115, doi: 10.1016/j.maturitas.2015.06.032, indexed in Pubmed: 26142653. 